Mineralogical Journal, Vol. 2, No. 3, Pr. 169-179, DEC., 1958

\title{
LONG SPACING CLAY MINERAL FROM THE UKU MINE, YAMAGUCHI PREFECTURE, JAPAN*
}

\author{
TAKeshi Mitsuda \\ Department of Geology and Mineralogy, Faculty of Science, \\ Hokkaido University
}

\begin{abstract}
A white powdery clay mineral with $28.8 \AA$. spacing was found in the kaolinite vein of the Uku mine, Yamaguchi Prefecture. The interplaner spacings of stronger X-ray powder diffraction lines of the mineral are as follows: $28.8 \pm 0.1$, $14.5 \pm 0.1,4.82 \pm 0.02$ and $1.4893 \pm 0.0005 \AA$.. The $14.5 \AA$. line shifts to $15.4 \pm 0.2 \AA$. and the $28.8 \AA$. line to $31.0 \pm 0.5 \AA$. after treatment with ethylene glycol. The $28.8 \AA$. line is persistent in the temperature range from $20^{\circ}$ to $300^{\circ} \mathrm{C}$, , but completely disappears above $400^{\circ} \mathrm{C}$.. The $14.5 \AA$. line is replaced by the $12.4 \AA$. line at $400^{\circ} \mathrm{C}$., which is persistent up to $600^{\circ} \mathrm{C}$. but disappears above $700^{\circ} \mathrm{C}$.: At $1200^{\circ} \mathrm{C}$. the specimen is transformed to mullite.

It is considered that, as $T$. Sudo et al. have already pointed out, the unusually long spacing of $28.8 \AA$. is the result of a regularly alternating stacking of two kinds of layer lattices; one is the ordinary montmorillonite lattice with the basal spacing of about $14.8 \AA$. and the other is a hypothetical aluminium chlorite lattice with the basal spacing of about $14.0 \AA$.
\end{abstract}

\section{Introduction}

The clay mineral with long spacing of about $30 \AA$. has been found in the clays from the Kurata mine, Yamaguchi Prefecture by $T$. Sudo, H. Takahashi and H. Matsui'), from the Hanaoka mine, Akita Prefecture by T. Sudo and H. Hayashi ${ }^{5}$, and from the Kamikita mine, Aomori Prefecture by T. Sudo, H. Hayashi, H. Kodama and K. Oinuma**. Recently the writer found a similar clay mineral from the

* Read at the Annual Meeting of the Mineralogical Society of Japan held in Tokyo on June 1, 1957.

** Refer to their paper read at the Annual Meeting of the Mineralogical Society of Japan held in Tokyo on June 1, 1957. 
Uku mine, Abu-machi, Yamaguchi Prefecture*. In the mode of occurrence, the Uku clay especially resembles the Kurata fire clay, both occurring in veins mainly composed of kaolinite.

A detailed study of the $30 \AA$. clay mineral was first attempted by $\mathrm{T}$. Sudo et al.45), who interpreted that the $30 \AA$. spacing is due to a regularly alternating stacking of two kinds of layer lattices; one is the ordinary montmorillonite layer lattice with the $15.4 \AA$. spacing, while the other is a hypothetical one with the $14.0 \AA$. spacing composed of a gibbsite and a pyrophyllite layers.

\section{Mode of occurrence}

As shown in Fig. 1 the ore bodies of the Uku mine are of lenti-

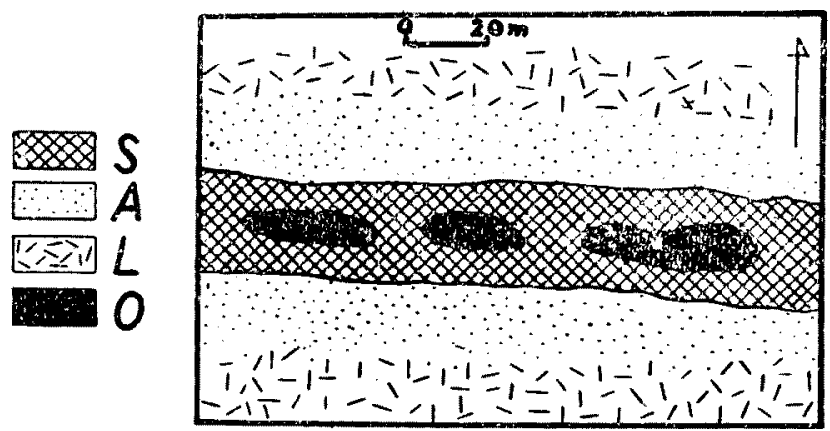

Fig. 1. Distribution map of country rocks and ore bodies of the Uku mine.

$S$ : silicious rock.

A: altered zone largely composed of sericite.

L: liparite.

$\mathrm{O}$ : ore bodies largely composed of andalusite.

cular shape, embedded at intervals in silicious rocks which extend east and west, and they are composed of andalusite, corundum and sericite, with small amounts of pyrophyllite, quartz, rutile and pyrite. Although almost all of these minerals are unaltered, in places, aluminous silicate minerals have altered to clay materials due to later hydrothermal actions. On the basis of the differential thermal analysis and X-ray powder data, the clay materials were identified to

* 山口罢 阿武町 宇久鉱山. 
be composed of kaolinite, diaspore and pyrophyllite.

The mode of occurrence of kaolinite veins including the long spacing clay mineral in question can be classified into two groups: one occurs as irregular network veinlets in flinty rocks and the other as a vein filled by powdery clay as illustrated in Fig. 2 . When the

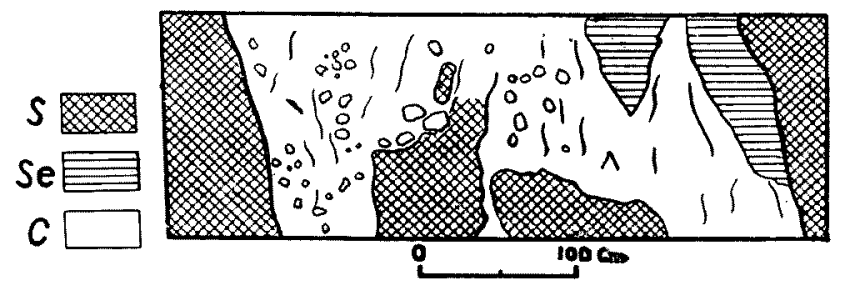

Fig. 2. Cross section of a clay vein in silicious rock.

$\mathrm{S}$ : silicious rock.

Se: sericite.

C: white powdery clay largely composed of kaolinite.

Sample (A) including the $29 \AA$. clay mineral was collected in this vein.

clay mineral of the latter group was treated with saturated aqueous solution of benzidine, some of it became slightly green. It is worth noticing that montmorillonite is generally tinged with green by benzidine.

The long spacing at about $29 \AA$. was observed in the $\mathrm{X}$-ray diffraction pattern of sample (A) separated from the clay which was tinged with green by benzidine.

\section{$X$-ray diffraction data}

The X-ray powder patterns of the clay specimens of the Uku mine were obtained by Philips Geiger Counter X-ray Spectrometer with filtered $\mathrm{Cu} K \alpha$ radiation. The experimental conditions were as follows: $35 \mathrm{kV} ., 13 \mathrm{~mA}$, time constant 4 seconds, scanning speed $2^{\circ}$ or $1 / 4^{\circ}$ per minute, angular aperture $1^{\circ}$, receiving slit 0.006 inch.

Spacings of the principal powder lines with $2 \theta$ angle lower than $8^{\circ}$ were accurately determined either by recording the reflection lines under scanning speed $1 / 8^{\circ}$ per minute with angular aperture 
$1 / 4^{\circ}$, or by calibrating their angles by referring to the powder lines of quartz or silicon, and further by counting their intensities at the fixed time of 64 seconds with scale factor 8.

\section{$X-r a y$ powder diffraction at room temperature}

The X-ray powder diffraction patterns of sample (A) are depicted in Fig. 3 and correlated in Table 1 to those of kaolinite, sericite, pyrophyllite and quartz except the 28.8 and $14.5 \AA$. lines. The reliability factors of their spacings are shown in Table 2.

The results are summerized as follows:

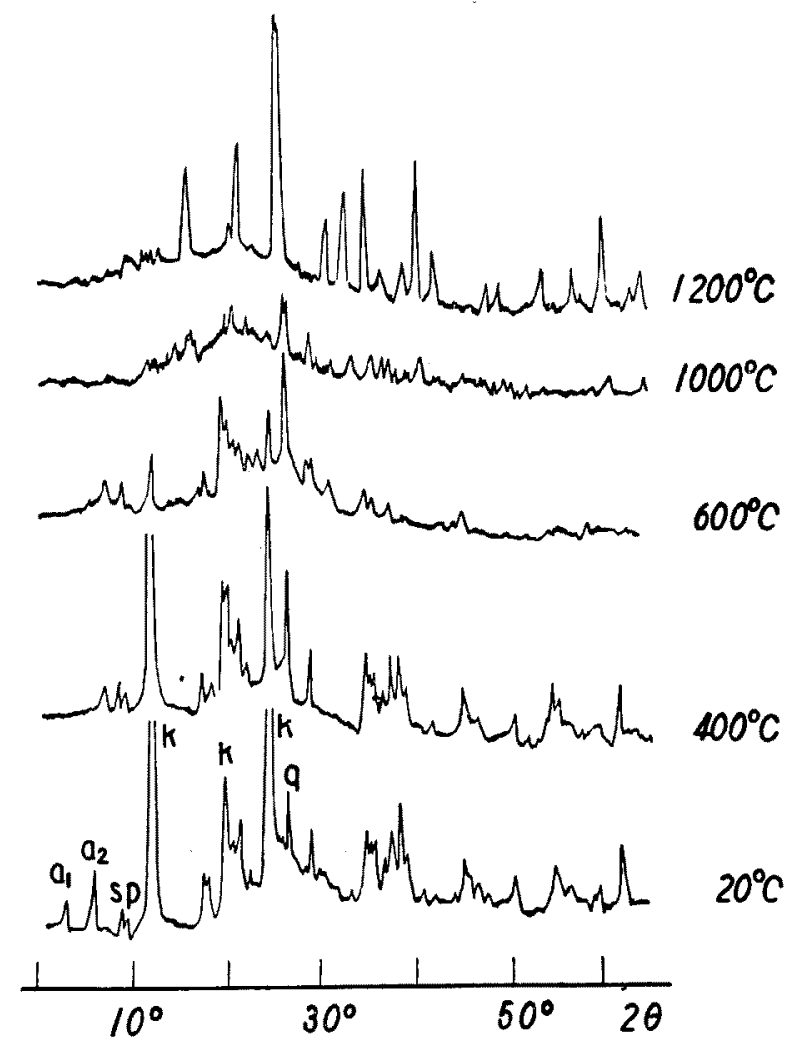

Fig. 3. X-ray diffraction patterns of sample (A).

$a_{1}, a_{2}: 00 l$ reflections from a basal spacing of $28.8 \AA$.

$\mathrm{K}$ : kaolinite, q: quartz, $\mathrm{S}$ : sericite, $\mathrm{P}$ : pyrophyllite. 
(1) It is clear that sample (A) is mainly composed of kaolinite

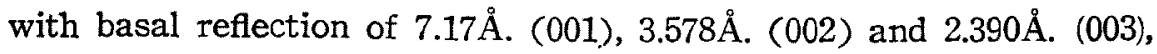
which is of slightly disordered type as revealed by unification of the close doublet, (1iī) and (11i).

(2) The $14.5,4.81,4.61$ and $2.30 \AA$. lines approximate to the reflections of montmorillonite, while the $14.5,7.17$ and $4.81 \AA$. lines approximate to the subsequent reflections of the $28.8 \AA$. line.

(3) The 4.26 and $3.34 \AA$. lines imply the presence of small amounts of quartz, 10.0, 5.00 and 3.34A. lines, that of sericite, and the $9.24 \AA$. line that of pyrophyllite.

(4) The spacing of (06) or (060) is $1.489 \AA$., which is similar to that of kaolinite and/or montmorillonite. It indicates that the principal clay minerals in sample (A) are of the dioctahedral type and that the number of aluminium ions in the tetrahedral coordination in the silica layer is quite small.

\section{Effect of heat treatment}

To ascertain the nature of the X-ray reflection of $28.8 \AA \AA$ spacing, the effect of heat treatment on X-ray powder pattern was investigated. Sample (A) was heated for one hour at every hundred degree interval between $100^{\circ}$ and $1200^{\circ} \mathrm{C}$. and each of the heated sample was examined by X-ray powder method after cooling to room temperature in the air.

The results obtained are shown in Fig. 3 and Table 1, and summerized as follows :

(1) It is the most important feature that the $28.8 \AA$. spacing is unaffected up to $300^{\circ} \mathrm{C}$, and on further heating at $400^{\circ} \mathrm{C}$. the $28.8 \AA$. line disappears completely and the $14.7 \AA$. line is replaced by the $12.4 \AA$. line, which is preserved up to $600^{\circ} \mathrm{C}$. but absolutely disappears above $700^{\circ} \mathrm{C}$.

(2) The pattern of kaolinite almost disappears at $600^{\circ} \mathrm{C}$. and completely at higher temperatures.

(3) In the temperature range of $20^{\circ} \sim 900^{\circ} \mathrm{C}$, the structures of 
Table 1. X-ray diffraction data for sample (A)

\begin{tabular}{|c|c|c|c|c|c|c|c|c|}
\hline \multirow{2}{*}{$\begin{array}{c}d(\text { calc. }) \text { for } \\
d(00 l)=28.8_{5} \AA\end{array}$} & \multirow{2}{*}{$\frac{\mathrm{S}}{h k l}$} & \multirow{2}{*}{$\frac{\mathrm{P}}{h k l}$} & \multirow{2}{*}{$\frac{\mathrm{K}}{h k l}$} & \multirow{2}{*}{$\frac{\mathrm{Q}}{h k l}$} & \multicolumn{2}{|c|}{$20^{\circ} \mathrm{C}$} & \multicolumn{2}{|c|}{$300^{\circ} \mathrm{C}$} \\
\hline & & & & & $d C$ & $I$ & $d(\AA)$ & $I$ \\
\hline $28.85 \AA ̊$ & \multirow{7}{*}{004} & \multirow{5}{*}{002} & \multirow{6}{*}{001} & \multirow{13}{*}{100} & $28.85^{* *}$ & 6 & $28.8^{*}$ & 5 \\
\hline 14.43 & & & & & 14. $5_{2} * *$ & $17 \mathrm{~s}$ & $14.4^{*}$ & $9 \mathrm{~s}$ \\
\hline & & & & & $10.0_{4} *$ & $8 \mathrm{~s}$ & 10.1 & $6 s$ \\
\hline 9.62 & & & & & 9. $24_{3} *$ & $5 s$ & 9.2 & 4 \\
\hline 7.21 & & & & & $7.17_{2}$ * & $200 \mathrm{~s}$ & 7.16 & $170 \mathrm{~s}$ \\
\hline 5.77 & & & & & $5.00_{6} *$ & $15 \mathrm{~s}$ & 5.01 & $10 \mathrm{~s}$ \\
\hline \multirow[t]{5}{*}{4.81} & & & & & $4.81_{9} *$ & 13 & 4.83 & 9 \\
\hline & \multirow{3}{*}{110} & & & & $4.61_{5}$ * & 6 & 4.60 & 5 \\
\hline & & & 020 & & $4.45_{7} *$ & $40 \mathrm{~s}$ & 4.45 & 40 \\
\hline & & & $1 \overline{1} 0$ & & 4.379 * & 22 & 4.37 & 30 \\
\hline & \multirow{18}{*}{$\left.\begin{array}{l}11 \overline{5} \\
025\end{array}\right)$} & & & & 4.269 * & 27 & 4.25 & 28 \\
\hline \multirow{3}{*}{$\begin{array}{l}4.12 \\
3.606\end{array}$} & & & $\begin{array}{l}11 \overline{1} \\
1 \overline{1} \overline{1})\end{array}$ & & 4. $14_{2}$ * & 15 & 4.14 & 14 \\
\hline & & & 002 & & 3. $57_{8}$ * & $180 \mathrm{~s}$ & 3.58 & $150 \mathrm{~s}$ \\
\hline & & 113 & & 101 & 3. $340^{*}$ & $15 s$ & 3.34 & $10 \mathrm{~s}$ \\
\hline \multirow[t]{14}{*}{2.885} & & & & & $2.976^{*}$ & $15 s$ & 2.976 & $11 \mathrm{~s}$ \\
\hline & & & $\left.\begin{array}{l}20 \overline{1} \\
130\end{array}\right)$ & & $\begin{array}{l}\text { 2. } 575^{*} \\
2.540^{*}\end{array}$ & $\begin{array}{r}20 \\
4\end{array}$ & $2.57_{5}$ & 23 \\
\hline & & & $13 \overline{1}$ & & 2. $505^{*}$ & 16 & 2.508 & 20 \\
\hline & & & 200 & & $2.440^{*}$ & 11 & 2.400 & $10 \mathrm{~b}$ \\
\hline & & & 003 & & $2.390^{*}$ & 20 & 2.396 & 20 \\
\hline & & & $\begin{array}{l}20 \overline{2} \\
131\end{array}$ & & $2.342^{*}$ & 28 & 2.351 & 25 \\
\hline & & & & & $2.301 *$ & 11 & 2.301 & 14 \\
\hline & & & $\begin{array}{l}203 \\
132)\end{array}$ & & $2.00^{*}$ & $10 \mathrm{~b}$ & 2.000 & $10 \mathrm{~b}$ \\
\hline & & & $13 \overline{3}$ & & 1. $943^{*}$ & 4 & 1.948 & 4 \\
\hline & & & 004 & & $1.792^{*}$ & 10 & 1.795 & 7 \\
\hline & & & $20 \overline{4}$ & & $1.662^{*}$ & 14 & $\begin{array}{l}1.666 \\
1.659\end{array}$ & $13 \mathrm{~b}$ \\
\hline & & & $\left.\begin{array}{l}133 \\
310\end{array}\right)$ & & $1.622^{*}$ & 5 & 1. 622 & $7 \mathrm{~b}$ \\
\hline & & & 203 & & $1.545^{*}$ & 5 & 1.544 & $4 b$ \\
\hline & & & $\left.\begin{array}{l}060 \\
13 \overline{1}\end{array}\right)$ & & $1.489 *$ & $17 \mathrm{~s}$ & 1.489 & $20 \mathrm{~s}$ \\
\hline
\end{tabular}

**: Spacing determined on the basis of the data of fixed time operation.

* : Spacing read on the chart recorded under the scanning speed $1 / 4^{\circ}$ per minute.

Other spacings were read on the chart recorded under the scanning speed $2^{\circ}$ per minute.

Relative intensities were estimated by amplitudes of peaks. 
T. MITSUDA

\begin{tabular}{|c|c|c|c|c|c|c|c|c|c|}
\hline \multicolumn{2}{|c|}{$500^{\circ} \mathrm{C}$} & \multicolumn{2}{|c|}{$600^{\circ} \mathrm{C}$} & \multicolumn{2}{|c|}{$900^{\circ} \mathrm{C}$} & \multicolumn{2}{|c|}{$1000^{\circ} \mathrm{C}$} & \multicolumn{2}{|c|}{$1200^{\circ} \mathrm{C}$} \\
\hline$d(\AA)$ & $I$ & $d(\AA)$ & $I$ & $d(\AA)$ & $I$ & $d(\grave{\AA})$ & $I$ & $d(\AA)$ & $I$ \\
\hline $12.4^{*}$ & $8 b$ & $12.4^{*}$ & $10 \mathrm{~b}$ & & & & & $5.41_{3}$ & $26 \mathrm{~s}$ \\
\hline 10.1 & $8 s$ & 10.1 & $10 \mathrm{~s}$ & 10.2 & 5 & & & $4.27_{5}$ & 10 \\
\hline 9.24 & $4 \mathrm{~s}$ & & & & & & & $4.09_{9}$ & $31 \mathrm{~s}$ \\
\hline 7.16 & $170 \mathrm{~s}$ & 7.16 & $15 s$ & & & & & $3.42_{9}$ & 67 \\
\hline 5.01 & $90 \mathrm{~s}$ & 5.01 & $8 \mathrm{~s}$ & 5.05 & $10 \mathrm{~s}$ & & & $3.40_{3}$ & 63 \\
\hline & & & & & & & & $2.89_{8}$ & $15 s$ \\
\hline$?$ & ? & & & & & & & $2.70_{0}$ & $27 \mathrm{~s}$ \\
\hline 4.47 & $32 \mathrm{~s}$ & 4.50 & $30 \mathrm{~s}$ & 4.50 & $20 \mathrm{~s}$ & & & $2.55_{0}$ & $33 \mathrm{~s}$ \\
\hline 4.37 & 20 & 4.37 & 20 & & & & & $2.43_{8}$ & 8 \\
\hline 4.24 & 20 & 4. 24 & 20 & 4.24 & 18 & 4.25 & 17 & $2.29_{2}$ & 11 \\
\hline 4.14 & 14 & & & & & & & 2.208 & 40 \\
\hline 3.58 & $160 \mathrm{~s}$ & 3.58 & 20 & & & & & 2. 127 & 15 \\
\hline 3.34 & $25 \mathrm{~s}$ & 3.34 & $25 \mathrm{~s}$ & 3.34 & $45 s$ & 3.14 & $13 \mathrm{vb}$ & 1.891 & 6 \\
\hline 2.97 & 12 & 3.1 & $8 b$ & 3.11 & $11 \mathrm{~s}$ & 3.11 & 7 & 1. 844 & 7 \\
\hline 2.57 & 18 & 2.59 & 7 & & & 2.70 & $6 \mathrm{~b}$ & 1.712 & 11 \\
\hline 2.508 & 15 & & & & & 2.53 & $5 b$ & 1. 602 & 11 \\
\hline 2.433 & 10 & & & & & 2.46 & $5 b$ & 1.527 & $26 \mathrm{~s}$ \\
\hline 2.390 & 20 & & & & & & & 1.460 & 5 \\
\hline 2.341 & 20 & & & & & & & 1.445 & 13 \\
\hline 2.301 & 8 & & & & & & & & \\
\hline 2.000 & 12 & 2.000 & 6 & & & & & & \\
\hline 1.948 & 4 & & & & & & & & \\
\hline 1.795 & 7 & & & & & & & & \\
\hline $\begin{array}{c}1.666 \\
?\end{array}$ & $\stackrel{12 b}{?}$ & & & & & & & & \\
\hline$?$ & ? & & & & & & & & \\
\hline 1.487 & 13 & & & & & 1.445 & 6 & & \\
\hline
\end{tabular}

s: sharp, b: broad, vb: very broad.

$\mathrm{Q}$ : quartz, K: kaolinite with indices after G.W. Brindleyl),

P: pyrophyllite with indices after J.W.Gruner ${ }^{3}$,

$S$ : sericite with indices after R. E. Grim2). 
sericite, pyrophyllite and quartz are not destroyed.

(4) The powder pattern lof the sample heated at $1200^{\circ} \mathrm{C}$. is similar to those of mullite.

\section{Effect of treatment with ethylene glycol and/or water}

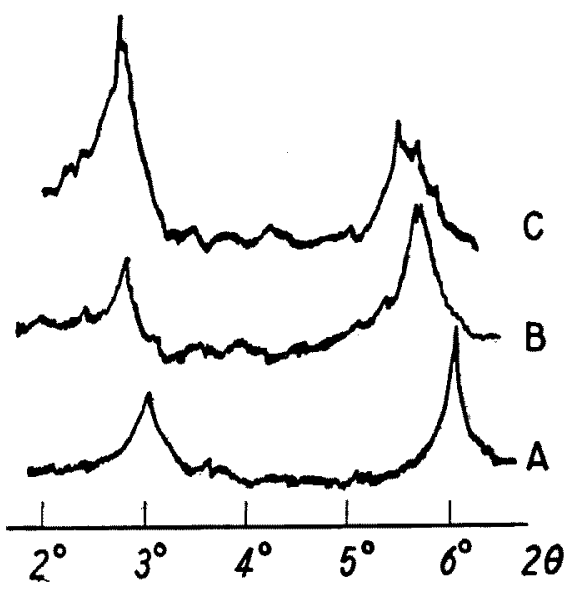

Fig. 4. Basal X-ray diffraction patterns for sample (A).

A : natural, $B$ : complexed with ethylene glycol, C: complexed with water.

The original sample (A) was pulverized, then covered completely with a few drops of ethylene glycol and/or water on slide-glass. The treated samples were studied by X-ray powder method, and the results obtained are shown in Fig. 4 and Table 2 ; they may be summerized as follows:

(1) The $14.5 \AA$. spacing expands to $15.4 \AA$. with ethylene glycol; this amount of expansion is less than that of the montmorillonite with two sheets of water molecules. While,

Table. 2. Basal X-ray diffraction data for long spacing clays.

\begin{tabular}{|c|c|c|c|c|c|c|}
\hline & \multicolumn{2}{|l|}{ Kurata4) } & \multicolumn{2}{|l|}{ Hanaoka5) } & \multicolumn{2}{|l|}{ Uku } \\
\hline & $d$ & $I$ & $d$ & $r$ & $d$ & $I$ \\
\hline$(001)$ & $29.8 \pm 0.5 \AA$ & $10 \mathrm{~s}$ & $29.6 \pm 0.2 \AA$ & $10_{3}$ & $28.8 \pm 0.1 \AA$ & 6 \\
\hline$(002)$ & $14.7 \pm 0.2$ & $15 \mathrm{~s}$ & $14.7 \pm 0.1$ & $18 \mathrm{~s}$ & $14.5 \pm 0.1$ & $17 \mathrm{~s}$ \\
\hline$(003)$ & $10.3 ?$ & $4 \mathrm{~b}$ & $9.8 \pm 0.1$ & 3 & & \\
\hline$(004)$ & $7.18 \pm 0.04$ & $20 \mathrm{~s}$ & $7.32 \pm 0.02$ & 5 & $7.17 \pm 0.02$ & $200 \mathrm{~s}$ \\
\hline$(005)$ & ? & & $5.99 ?$ & 3 & ? & \\
\hline$(006)$ & $4.95 \pm 0.05$ & $10 \mathrm{~s}$ & $4.91 \pm 0.02$ & $10 \mathrm{~s}$ & $4.82 \pm 0.02$ & 13 \\
\hline$(009)$ & $3.32 \pm 0.02$ & $6 \mathrm{~b}$ & $3.30 \pm 0.02$ & 5 & ? & \\
\hline$(00,10)$ & $3.03 \pm 0.06$ & $4 \mathrm{~b}$ & $2.97 \pm 0.06$ & 2 & $2.97 \pm 0.01 ?^{*}$ & $15 \mathrm{~s}$ \\
\hline$(060,331)$ & $1.4919 \pm 0.0002$ & $15 \mathrm{~s}$ & $1.5057 \pm 0.0008$ & $8 s$ & $1.4893 \pm 0.0005$ & $17 \mathrm{~s}$ \\
\hline
\end{tabular}

* The spacing $2.97 \AA$ is superposed by that of sericite. 
T. Mitsuda

Complexed with ethylene glycol

\begin{tabular}{l|l|l|l}
\hline & \multicolumn{1}{|c|}{ Kurata } & \multicolumn{1}{|c}{ Hanaoka } & \multicolumn{1}{c}{ Uku } \\
\hline$(001)^{\prime}$ & $32.3 \pm 0.5 \AA$ & $31.6 \pm 0.2 \AA$ & $31.0 \pm 0.5 \AA$ \\
$(002)^{\prime}$ & $15.6 \pm 0.3$ & $15.6 \pm 0.1$ & $15.4 \pm 0.2$ \\
\hline
\end{tabular}

the $28.8 \AA$. spacing expands to $31.0 \AA$. at the rate twice as great as in the case of the $14.5 \AA$. spacing.

(2) Upon treatment with water, the $14.5 \AA$. spacing expands to about $16 \AA$. and that of $28.8 \AA$. to $31 \sim 32 \AA$..

These facts suggest that $28.8 \AA$. and $14.5 \AA$. lines may be related to the presence of the montmorillonite lattice.

\section{Differential thermal analysis curve}

Heating rate for differential thermal analysis was $10^{\circ} \mathrm{C}$. per minute. The differential thermal analysis curve of sample (A), as shown in Fig. 5, displays the following peaks:

(1) A clear endothermic peak in the temperature range of $100^{\circ} \sim 200^{\circ} \mathrm{C}$. and a weak one in $200^{\circ} \sim 300^{\circ} \mathrm{C}$.

(2) A sharp endothermic peak at about $600^{\circ} \mathrm{C}$. and a broad weak one in the temperature range of $700^{\circ} \sim 800^{\circ} \mathrm{C}$..

(3) Finally, a sharp exothermic peak in the range of $900^{\circ} \sim 1000^{\circ} \mathrm{C}$.. Those peaks reveal that sample (A) analysis curve for sample (A). includes both kaolinite and montmorillonite.

\section{Chemical analysis}

The chemical analysis of sample (A) gave the following results: $\mathrm{SiO}_{2} 45.83, \mathrm{Al}_{2} \mathrm{O}_{3} 40.37, \mathrm{Fe}_{2} \mathrm{O}_{3}$ 0.61, $\mathrm{TiO}_{2}$ 0.11, $\mathrm{CaO} 0.15, \mathrm{MgO} 0.07, \mathrm{~K}_{2} \mathrm{O}$ 
and $\mathrm{Na}_{2} \mathrm{O}$ trace, $\mathrm{H}_{2} \mathrm{O}(+) 12.49, \mathrm{H}_{2} \mathrm{O}(-) 0.85$, total $100.48 \%$ (analyst, Goro Shibuya).

Taking into consideration the fact that the intensity of the 7.17 . line of sample (A) is the strongest as well as the chemical composition of the sample, it may be concluded that the most dominant component of the Uku clay is kaolinite.

\section{Discussion}

The observed spacings of the long spacing clay minerals from Kurata ${ }^{4}$, Hanaoka ${ }^{5)}$ and Uku are compared in Table 2. They are generally in good agreement with each other, but differ slightly with regard to their relative intensities as well as to the spacing of (001).

The spacing of (001) of the clay mineral from Uku is a little smaller than that from Kurata or Hanaoka. It may be considered that the montmorillonite layer composing the clay minerals from Kurata and Hanaoka have the basal spacing of $15.4 \AA$. with two sheets of water molecules, whereas that from Uku, 14.8A.. Actually, a certain specimen from the same locality as sample (A) produced a diffraction line at $14.8 \AA$. while lacking the long spacing of about $29 \AA$.. The $14.8 \AA$. spacing of this specimen was identified as the basal spacing of montmorillonite by means of X-ray and thermal studies.

Accepting T. Sudo's idea on the $30 \AA$. clay mineral, the long spacing observed for the sample from the Uku mine may be interpreted as follows:

The long spacing of $28.8 \AA$. is caused by a regularly alternating stacking of two kinds of layer lattices: one is the usual montmorillonite lattice with about two sheets of water molecules and a cell height of $14.8 \AA$. which is expected to decrease to $10.8 \AA$. by dehydration and to expand to about $17.0 \AA$. by the treatment with ethylene glycol; the other is an aluminium chlorite lattice with a cell height of about $14.0 \AA$. which is expected to be unaffected by the treatment with ethylene glycol and/or water and may be persistent at least up to $600^{\circ} \mathrm{C}$.. 


\section{Acknowledgements}

The writer is greatly indebted to Professor Zyunpéi Harada, Hokkaido University, for reading this manuscript and offering significant suggestions. Thanks are due to Professor Toshio Sudo, Tokyo University of Education, for helpful suggestions, and to Mr. Goro Shibuya, Yamaguchi University for chemical analysis. The writer also acknowledge to Mr. Hiroshi Noguchi, the President of the Nihon Firebrick Company for affording facilities for field survey.

\section{REFERENCES}

1) Brindley, G.W.: X-ray identification and crystal structures of clay minerals, (1951).

2) Grim, R.E., R.H. Bray and W.F. Bradley.: Amer. Miner., 22, 813 (1937).

3) Gruner, J.W.: Zeit. Krist., 88, 412 (1934).

4) Sudo, T., H. Takahashi and H. Matsui : Nature, 173, 261 (1954).; Jap. Journ. Geol. Geograph., V, 24, 71 (1954).

5) Sudo, T. and H. Hayashi : Science Reports of the Tokyo Kyoiku Daigaku, C, No. 25 (1955).

Manuscript received September 28, 1957. 